\title{
TARZYCJUSZ BuLIŃSKI
}

Uniwersytet Gdański

\author{
ALEKSANDER POSERN-ZieLIŃSKI ID
}

Uniwersytet im. Adama Mickiewicza w Poznaniu

\section{Etnografia osobista. Antropolożka i antropolog w terenie}

$\mathrm{M}$ amy przyjemność przekazać do rąk Czytelników wyjątkowy numer monograficzny czasopisma, poświęcony doświadczeniom terenowym polskich antropolożek i antropologów ${ }^{1}$. Wyróżnić można dwa powody jego unikalności. Pierwszym jest okazja jego wydania. Tom monograficzny, który prezentujemy, publikujemy z okazji jubileuszu 70-lecia ks. Profesora Wojciecha Bębna oraz zakończenia Jego bogatej kariery akademickiej. Osoba ks. Profesora jest nietuzinkowa w polskiej antropologii. Z jednej strony jest On jednym z nielicznych polskich kontynuatorów antropologicznych badań Oceanii uprawianych w duchu Bronisława Malinowskiego, z drugiej zaś - jest On badaczem o przebogatym doświadczeniu terenowym. Właściwie trudno wskazać drugiego współczesnego polskiego etnografa Oceanii i Australii, który doświadczyłby tylu pobytów terenowych wśród ludów tubylczych Nowej Gwinei, Oceanii i Australii. Postanowiliśmy więc uhonorować Jego karierę numerem monograficznym czasopisma związanego z gdańskim ośrodkiem etnologii, założonym właśnie przez ks. Profesora. Drugi powód unikalności tego numeru czasopisma jest związany z wyborem tematyki. Otóż postanowiliśmy skoncentrować się w nim na kwestii, która do tej pory nie była przedmiotem uporządkowanej refleksji w polskiej

${ }^{1}$ Pod hasłem „antropologia” będziemy rozumieć jedną i tę samą dyscyplinę naukową określaną podobnymi, choć różniącymi się, nazwami: antropologią społeczną, antropologią kulturową i etnologią, w zależności od kręgu kulturowo-językowego i czasowego. Jest to jednak zawsze ta sama nauka, zajmującą się poznawaniem zróżnicowania kulturowego ludów świata za pomocą metody badań etnograficznych. 
literaturze antropologicznej, choć oczywiście pojawiała się jako myśl poboczna czy marginalna. Chodzi o ukazanie antropologicznych badań terenowych nie poprzez pryzmat metodologicznych problemów metody etnograficznej, lecz od strony osobistych doświadczeń samego badacza. Niniejszym numerem chcemy choćby częściowo wypełnić tę lukę.

\section{Etnografia osobista}

Jaka przyświeca nam myśl główna? Chcemy pokazać Czytelnikowi nie tyle tajniki warsztatu etnografa - choć $\mathrm{w}$ tekstach zebranych w czasopiśmie da się odnaleźć także i takie wskazówki - co przybliżyć wymiar praktyczny, egzystencjalny i emocjonalny antropologicznych badań terenowych. Nazwaliśmy go „etnografią osobistą". Każde z badań etnograficznych nie jest bowiem realizowane w "próżni” społecznej i materialnej, lecz w bardzo konkretnym miejscu i czasie, wśród danych ludzi, w konkretnych warunkach bytowych, w danej sytuacji politycznej, społecznej i ekonomicznej. I co najważniejsze - w trakcie ich realizacji tworzą się konkretne emocje, które później budują wspomnienia z terenu. Innymi słowy, badania etnograficzne są zawsze ucieleśnione, przybierają niepowtarzalny, indywidualny kształt dla osób je współtworzących - zarówno dla antropologa, jak i dla ludzi, z którymi pracuje. Etnografia osobista to pamięciowy zapis niepowtarzalnych, indywidualnych doświadczeń antropologów, przeżytych w trakcie prowadzenia badań terenowych. Doświadczeń, które nie są bezpośrednim efektem działań badawczych i które najczęściej nie zostają włączone do wyników prac naukowych (książek, artykułów). Nie oznacza to wszak, że nie istniały i że nie miały one wpływu na uzyskane wyniki badawcze. Jak się wielokrotnie Czytelnik przekona $\mathrm{w}$ trakcie lektury poniższych artykułów, to właśnie ślepe trafy i przypadkowo napotkane osoby miały kluczowe znaczenie w organizacji badań terenowych, a później stawały się ważnymi osobami w życiu osobistym badacza. $\mathrm{W}$ antropologii sam badacz jest narzędziem $\mathrm{i}$ bada za pomocą samego siebie, $\mathrm{tj}$. doświadczeń, które przeżywa (zob. Buliński, Kairski 2011b).

Etnografia osobista dotyczy zatem wszystkiego, co formalnie nie należy do metody badań etnograficznych, nie jest elementem metodyki, technik i narzędzi badawczych. Obejmuje wycinek procesu życia antropolożki czy antropologa, który jest niezbędny do zastosowania metody naukowej przez nią lub przez niego. Badacze bowiem, oprócz wykonywania w terenie samych badań (np. prowadzenia wywiadów czy obserwacji), muszą w nim także żyć (np. przygotowywanie posiłków, spanie, pranie swoich ubrań czy odpoczywanie). Dla antropologów jest oczywiste, że suma ich doświadczeń terenowych zdecydowanie przekracza to, co jest zawarte w ich publikacjach naukowych. Większość z nich uważa, że nie warto o tym pisać $w$ tekstach naukowych, gdyż życie $w$ terenie jest niezbędnym warunkiem przeprowadzenia badań i jako takie nie powinno mieć dużego wpływu na uzyskane wyniki badawcze. Jeśli więc wątek etnografii osobistej pojawia się 
w pracach antropologicznych, to najczęściej przy opisie metodyki badawczej². My jednak sądzimy, że przedstawienie „kuchni” badań antropologicznych jest ważne z co najmniej trzech względów.

Po pierwsze dlatego, że pomaga w doskonaleniu warsztatu badawczego antropologa. Już od ponad dwóch dekad tzw. wąskie pojmowanie terenu, który $\mathrm{w}$ tradycyjnie ujmowanej antropologii widziany był jako obszar prowadzenia badań (terytorium fizyczne lub wirtualne), przestało wystarczać do opisu praktyki etnograficznej. Współczesna antropologia odwołuje się do tzw. szerokiego rozumienia terenu, jako wielowymiarowej metafory myślowej i pojęciowej, próbującej w miarę wiernie oddać sytuację interakcji badacza z ludźmi, z którymi pracuje. Terenem są więc relacje i procesy uruchomione przez praktykę etnograficzną, w wielu wypadkach przez nią także przekształcane. Wszystkie podmioty biorące w niej udział (antropolożki, antropolodzy, ludzie, z którymi pracują) na nią wpływają i ją przeobrażają. Etnografia osobista pozwala zdać sprawę z czynników, które oddziaływają na proces badawczy i mogą wpływać na jego końcowy efekt. Ich poznanie pozwala na „zrobienie” lepszej antropologii, tj. takiej, która precyzyjniej zdaje sprawę z genezy lub funkcjonowania jakiegoś zjawiska. Po drugie, wątki podejmowane w etnografii osobistej mają istotne znaczenie dla dokumentowania dziejów badań antropologicznych w Polsce. Wiele kwestii o kluczowym znaczeniu faktograficznym, pozwalających odtworzyć powody, przebieg i rodzaje efektów naukowych polskich badań etnograficznych, jest przedstawianych na ogół w tekstach usytuowanych na obrzeżach literatury naukowej. A bez tych kwestii zrozumienie i wyjaśnienie historii polskiej etnologii jest utrudnione. Po trzecie wreszcie, etnografia osobista odgrywa niebanalną rolę podczas kształcenia nowych adeptów etnografii, studentów i doktorantów. Pokazuje w nowym świetle dokonania naukowe uznanych antropolożek i antropologów, osób o dużym dorobku naukowym i cieszących się autorytetem w społeczności antropologicznej. Pozwala dostrzec, że każdy etnograf staje w swoim terenie przed szeregiem wyzwań o charakterze praktycznym, etycznym i egzystencjalnym. I choć wydają się one podobne, to - jak pokazują teksty zgromadzone w tym tomie - ich rozwiązywania nie sposób sprowadzić do zastosowania procedury z podręcznika do badań etnograficznych. Każdorazowo, każda z osób piszących w tym tomie, stawała przed niepowtarzalnymi indywidualnymi wyzwaniami i rozwiązywała je na swój niepowtarzalny sposób. Lektura tych rozwiązań oferuje pomoc w edukacji przyszłych adeptów dyscypliny.

\footnotetext{
2 Istnieją trzy rodzaje tekstów, napisanych przez antropologów, poświęconych oddaniu specyfiki „życia w terenie”. Pierwszy typ to świadomie pisane dzienniki terenowe przybierające formę literacką (np. Malinowski 2008). Drugim typem są napisane post factum prace relacjonujące przebieg doświadczenia terenowego świadomie przyobleczonego $\mathrm{w}$ formę literatury faktu (np. Barley 1997). Wreszcie trzecim typem są rozprawy metodologiczne dotyczące metody etnograficznej (np. Marcuse 2010).
} 


\section{Autoetnografia a etnografia osobista}

Przy tak określonej idei etnografii osobistej konieczne jest odniesienie jej do nurtu autoetnografii - powstałego na przełomie lat 70. i 80. XX w., zróżnicowanego zespołu postulatów i technik badawczych w obrębie socjologii jakościowej, wychodzącego naprzeciw postulatom postmodernistycznym i stanowiącego jedną z odpowiedzi nauk społecznych i humanistycznych na tzw. „kryzys reprezentacji”. W najprostszym ujęciu autoetnografia to technika badawcza, w której badacz sam wywołuje źródła dotyczące jego doświadczeń osobistych (np. na podstawie samoobserwacji prowadzi dziennik badawczy), a następnie używa ich do analizy kulturowego i społecznego świata, w którym żyje na co dzień3

Widać tu zatem pewne zbieżności z ideą etnografii osobistej. Po pierwsze, jest nią wspólnota założeń. Oba podejścia podzielają model epistemologiczny, który zakłada procesualność i refleksywność poznania. W związku z tym informacje dostarczane przez osobę badacza, i to nie tylko w trakcie badań, ale także i długo po nich, są uznawane jako wartościowe. Stąd też w obu przypadkach wskazane jest podejmowanie krytycznej, refleksywnej analizy doświadczeń osobistych badacza. Po drugie, widać wspólnotę stosowanych technik badawczych, tj. obserwacji oraz regularnego zapisywania jej wyników w dzienniku badawczym. Po trzecie wreszcie, wszystkie te działania nie są wartością samą w sobie, lecz czemuś służą - zrozumieniu doświadczenia kulturowego w przypadku autoetnografii, doskonaleniu warsztatu badawczego antropologa - w przypadku etnografii osobistej.

Niemniej są także i różnice. Pierwszą z nich jest odrębność tematów badawczych. Czego najczęściej dotyczą teksty autoetnograficzne? Otóż podejmują one specyficzne kwestie koncentrujące się na doświadczeniach cielesnych i związanych nimi emocjach, stanach, myślach (choroba, adopcja, wykorzystanie seksualne, niepełnosprawność, doświadczenie pracy jako kierowcy ciężarówki itp.). W skrócie można je określić jako doświadczenia graniczne Natomiast etnografię osobistą interesuje znacznie szersze spektrum doświadczeń osobistych antropolożki lub antropologa w terenie, obejmujące nie tylko wymiar cielesny i emocjonalny, ale także praktyczny i organizacyjny. Po drugie, narracje autoetnograficzne są głównym źródłem poznawczym, a nie pomocniczym, jak w przypadku etnografii osobistej. Teksty w niniejszym tomie stanowią dopełnienie głównych prac badawczych ich autorów. Po trzecie, antropolodzy nie są pełnymi uczestnikami badanego świata, nie są "tubylcami”, tak jak to ma miejsce w przypadku autoetnografów.

Podsumowując, można powiedzieć, że autoetnografia jest odrębnym nurtem w dziedzinie badań społecznych i wykazuje podobieństwa z ideą etnografii

\footnotetext{
${ }^{3}$ Wyróżnić można jej dwie zasadnicze odmiany: autoetnografię krytyczną i ewokatywną. Ta pierwsza jest połączeniem narracji osobistych badacza z innymi technikami badawczymi i analizą danych zastanych. Ta druga natomiast traktuje narrację badacza jako jedną spójną opowieść na pograniczu nauki i sztuki, która ma przede wszystkim wywołać emocjonalny efekt w odbiorach. Oczywiście nurtów praktykowania i sposobów rozumienia autoetnografii jest więcej (zob. np. Kacperczyk 2014; Kafar 2009; Holman 2009).
} 
osobistej głównie w kwestii wspólnego punktu wyjścia i stosowanych technik badawczych. Oba podejścia różnią się zasadniczo w kwestii celów badawczych, podejmowanej problematyki, jak i metodologii. Błędem byłoby ich utożsamianie.

\section{Doświadczenia i wspomnienia terenowe}

Naszą intencją było, aby konstrukcja i zawartość tomu poświęconego ks. Profesorowi Wojciechowi Bębnowi z jednej strony odpowiadała pasjom i działalności Jubilata, a z drugiej tworzyła jednorodną całość, inspirującą i zarazem ciekawą dla Czytelnika. Ze względu na ściśle określone zainteresowania regionalne Profesora Wojciecha Bębna (ludy rdzenne Nowej Gwinei, Oceanii i Australii), potencjalną osią konstrukcyjną tomu mogłyby być specjalistyczne studia poświęcone badaniom prowadzonym na obszarze Wysp Pacyfiku. Jednakowoż takie zadanie było w istocie niewykonalne, ponieważ - jak się okazuje - w polskim środowisku etnologicznym obszar ten (mimo znakomitych tradycji wynikających z badan J. Kubarego, B. Malinowskiego i A.L. Godlewskiego) był (i jest nadal) eksplorowany niezwykle skromnie, a właściwie incydentalnie. Stąd też formuła numeru musiała przybrać kształt bardziej uniwersalny.

Konstrukcja i tytuł niniejszego tomu w oczywisty sposób nawiązuje do pozycji pt. Teren w antropologii. Praktyki badawcze we wspótczesnej antropologii (Buliński, Kairski 2011a). Staraliśmy się w niej zebrać wypowiedzi polskich badaczek i badaczy dotyczące nowoczesnego, szerokiego pojmowania terenu w antropologii. W niniejszym numerze monograficznym czasopisma kontynuujemy tę linię rozważań, tym razem zajmując się przybliżeniem osobistych doświadczeń z badań terenowych. Do udziału w nim zaprosiliśmy antropolożki i antropologów ze wszystkich generacji społeczności akademickiej w Polsce. Wszyscy autorzy mają doświadczenie terenowe. Jest ono wprawdzie zróżnicowane pod względem skali (w tomie są teksty autorów mających zarówno 50-letnie, jak i 10-letnie doświadczenia badawcze), lecz jest podobne pod względem pasji przebywania w terenie. To cecha wspólna i oś konstrukcyjna całej książki.

Pod względem usytuowania geograficznego prowadzonych studiów tom zawiera artykuły poświęcone refleksjom z badań prowadzonych w Ameryce Łacińskiej (Aleksander Posern-Zieliński, Paweł Chyc, Kacper Świerk, Eugeniusz Kłosek) w Ameryce Północnej (Patrycja Trzeszczyńska), w Afryce (Ryszard Vorbrich, Maciej Ząbek) oraz w Azji (Natalia Bloch, Rafał Beszterda, Łukasz Smyrski, Sylwia Pietrowiak). Dobrym uzupełnieniem uwag zebranych na polu pozaeuropejskich doświadczeń terenowych stały się także eseje tych autorów, którzy podzielili się swymi obserwacjami zebranymi w trakcie badań prowadzonych na obszarze europejskim (Katarzyna Mirgos), czy też w granicach naszego kraju (Lech Mróz, Katarzyna Kość-Ryżko, Kamil Pietrowiak, Magdalena Zowczak, Tomasz Rakowski).

Sądzimy, że połączenie obu nieco odmiennych perspektyw badawczych (etnograficzne doświadczenia terenowe z wielu regionów świata) podkreśli 
kolejny raz, iż niezależnie od badanego kontekstu kulturowego i dystansu cywilizacyjnego, sytuacja antropologa, $\mathrm{w}$ terenie bliskim lub bardzo dalekim, pozornie swojskim, jak i kompletnie obcym, jest nierzadko bardzo zbliżona pod względem warsztatowym, psychologicznym, a nawet egzystencjalnym. Nie oznacza to jednak, że specyfika spotkania antropologa z badaną przez niego społecznością i jej kulturą nie ma wpływu na charakter pracy terenowej. Dobór publikowanych tu artykułów związek ten wyraziście podkreśla. Tak więc możemy zapoznać się z typem doświadczeń terenowych powstałych $\mathrm{w}$ trakcie kontaktów z ludami tubylczymi, i to o znacznym stopniu izolacji (np. w Amazonii), ze społecznościami wiejskimi charakterystycznymi dla krajów postkolonialnych (np. w Indiach, Chile, Sudanie); niektóre ze szkiców poświęcone są imigracyjnym wspólnotom diasporowym (Polonia w Brazylii, Ukraińcy w Kanadzie) oraz etnicznym grupom mniejszościowym (Baskowie w Hiszpanii, Romowie/Cyganie w Polsce); wreszcie możemy także przyjrzeć się specyfice badań etnograficznych w naszym kraju, choć prowadzonych w dość „niety powych” środowiskach (niewidomi, Sybiracy). W ten sposób powstała swoista panorama autorefleksyjnych opowieści, przywołujących doświadczenia z różnych etnograficznych "spotkań". Ich autorami są wytrawni badacze reprezentujący niemal wszystkie akademickie ośrodki studiów z zakresu etnologii/antropologii. Obok przyjaciół, współpracowników i kolegów Jubilata, wkład do tego tomu wnieśli także i ci badacze, którzy z szacunku dla dorobku Profesora Wojciecha Bębna i Jego pozycji w polskiej etnologii, postanowili podzielić się swymi doświadczeniami terenowym, w przekonaniu, iż suma tego rodzaju uwag będzie najlepszym sposobem uhonorowania Jubilata.

Całość numeru podzieliliśmy na dwie główne części. Część pierwsza (Wojciech Bęben - polski badacz Oceanii i Australii) poświęcona została zaprezentowaniu sylwetki ks. Profesora Wojciecha Bębna, jako etnologa, religioznawcy, kolekcjonera, akademickiego wykładowcy, założyciela gdańskiego ośrodka studiów etnologicznych i zarazem misjonarza. O bardzo nietypowej naukowej drodze Jubilata (w porównaniu z większością karier polskich etnologów/antropologów), wiodącej od seminarium duchownego w Pieniężnie, przez wieloletnie pobyty na Nowej Gwinei, w Australii i na Nowej Zelandii, aż do profesury na Uniwersytecie Gdańskim, pisze M. Kairski, ukazując w swym szkicu Wojciecha Bębna nie tylko jako naukowca z pasją poznającego odmienne kultury, ale również jako człowieka w pełni otwartego na inne światy i potrafiącego z goszczącymi go tubylcami dzielić codzienne troski. Osobny esej przedstawia Profesora Wojciecha Bębna w roli zasłużonego organizatora życia naukowego, jako inicjatora, założyciela ośrodka etnologicznych studiów na Uniwersytecie Gdańskim, którym następnie kierował, przez lata wzmacniając jego podstawy. O tych dokonaniach, w ewidentny sposób wzbogacających instytucjonalną panoramę polskiej etnologii/antropologii oraz wypełniających widoczną lukę w akademickim świecie humanistyki na Pomorzu, pisze J. Splisgart. Z kolei w wywiadzie, przeprowadzonym przez B. Jutrzenkę-Trzebiatowską z Profesorem W. Bębnem, Jubilat miał możliwość podzielenia się w swobodnej formule refleksjami wynikającymi z tak bogatych i różnorodnych doświadczeń życiowych. Uzupełnieniem tego zbioru 
szkiców, ukazujących z różnych perspektyw postać Jubilata, jest również tekst laudacji wygłoszonej przez A. Posern-Zielińskiego na Uniwersytecie Jagiellońskim, w trakcie uroczystości wręczenia Profesorowi Wojciechowi Bębnowi prestiżowej Nagrody im. Benedykta Polaka, a więc wyróżnienia przyznawanego naukowcom nie tylko wybitnym, ale takim, którzy poprzez swe peregrynacje wzbogacili naszą wiedzę o dalekich lądach i ludach.

Część druga numeru (Osobiste wymiary doświadczeń etnograficznych) została podzielona na cztery działy, z których każdy ogniskuje się wokół jednego, najbardziej widocznego $\mathrm{w}$ tych szkicach tematu. W dziale pierwszym (Inicjacyjne, i nie tylko, wspomnienia z terenu) przewodni jest motyw doświadczenia terenowego jako swoistej inicjacji etnograficznej, a także wątek przygód, przeżyć, wydarzeń szczególnie zapadających $w$ pamięć i przywoływanych po latach w osobistych wspomnieniach. Tego rodzaju refleksje wybijają się na plan pierwszy w artykułach K. Mirgos, M. Zowczak, M. Ząbka, L. Mroza i S. Pietrowiak. Zwracają oni wszyscy uwagę na szczególne znaczenie pierwszych, najwcześniejszych faz doświadczeń etnograficznych, które pełniły w dużym stopniu rolę swoistego obrzędu przejścia, prowadzącego od prób dość chaotycznego rozpoznawania specyfiki badanego terenu do późniejszych etapów dobrze skonceptualizowanych, a więc profesjonalnych, penetracji. Te pierwsze kontakty $\mathrm{z}$ terenem, $\mathrm{z}$ obcym kulturowo czy etnicznie środowiskiem, nie były zazwyczaj łatwe, gdyż odrywały one badacza, i to często na długi okres, od bliskich i swojskiego otoczenia, wtłaczały go w nieoczekiwaną samotność i zagubienie w nieznanym środowisku. W takiej sytuacji nieuchronnie ujawniały się subiektywne trudności, wynikające z nieprzygotowania na ten rodzaj wyzwań czy z braku odporności na stres. Pokonywanie tych przeszkód, także i obiektywnych, wynikających z warunków, $\mathrm{z}$ jakimi spotykał się badacz $\mathrm{w}$ terenie, stopniowo uodporniało etnografa, czyniło go bardziej adaptabilnym, ułatwiało nawiązywanie kontaktów, a co za tym idzie - prowadziło do większej efektywności działań.

Otwarte spojrzenie na te osobiste doświadczenia ujawnia także pokłady różnorakich emocji, jakie nieuchronnie towarzyszą badaczowi $w$ terenie; $z$ jednej strony są to autentyczne fascynacje spotkaniami z odmienną kulturą, z drugiej pojawiają się także uczucia zawodu, zmęczenia, rozczarowania czy zniechęcenia. Autorzy tych wspomnień wskazują również na niebagatelne znaczenie zmysłów w postrzeganiu i oswajaniu "terenu" - a więc widoków, dźwięków, zapachów, smaków; podkreślają także i to, jak niezbędna jest konieczność wypracowania $\mathrm{w}$ sobie szeregu niezbędnych cech, często sprzecznych $\mathrm{z}$ własnym typem osobowości, takich jak cierpliwość, wytrzymałość, samozaparcie, odporność na permanentny brak prywatności czy umiejętność radzenia sobie w sytuacjach kryzysowych. Autorzy wskazują także na znaczenie stopniowego odkrywania skutecznych metod dla praktyki etnograficznej, polegających na nabywaniu umiejętności antropologicznej interpretacji pozornie błahych, drobnych, incydentalnych czy wręcz codziennych wydarzeń i spotkań. Wraz z tą refleksją pojawia się także motyw mozolnego zdobywania kompetencji terenowych, niewiele mających wspólnego z gabinetowymi, akademickimi rekomendacjami, dzięki którym 
badacz powoli „wnika” w nowe środowisko i rozpoczyna proces żmudnego "uczenia się" a następnie „rozumienia” otaczającej go kultury. Co ciekawe, autorzy tych wspomnień, zwykle bardzo osobistych i często dopiero teraz ujawnianych, podkreślają wagę i znaczenie swych pierwszych lat badań, pisząc, iż z odległej czasowo perspektywy ukazują one swój doniosły wymiar, jako wydarzenia trwale zapisane $\mathrm{w}$ pamięci i mocno odciśnięte $\mathrm{w}$ pokładach doświadczenia.

Ważną sferą autorefleksji etnograficznej są wspomnienia, uwagi i rekomendacje dotyczące specyfiki nawiązywania relacji z informatorami, czy to bliskimi nam kulturowo i społecznie, czy też należącymi do świata „tubylczego". To od charakteru i dynamiki tych kontaktów, ich zakresu oraz intensywności, zależy przecież nie tylko codzienna egzystencja etnografa w terenie, ale przede wszystkim efektywność badań oraz rzetelność uzyskanych informacji. Ten temat przewija się w sposób najbardziej widoczny $\mathrm{w}$ artykułach $\mathrm{w}$ dziale drugim (Formy wspótpracy $z$ "tubylcami"), napisanych przez N. Bloch, R. Vorbricha, P. Trzeszczyńską i A. Posern-Zielińskiego. Autorzy podkreślają, że jednym z ważnych warunków powodzenia badań jest budowa relacji zażyłości z członkami wspólnoty, w obrębie której antropolog przebywa. Te bliskie relacje przybierają często charakter dalece przekraczający ramy profesjonalnego kontaktu, obejmując sfery zażyłości zarezerwowane zwykle dla osób bliskich, krewnych czy przyjaciół. Ważną strategią efektywnego postępowania $w$ terenie jest także dotarcie do osób kluczowych, a więc takich, których pomoc i rekomendacje są niezbędne $\mathrm{w}$ procesie pozyskiwania szczególnie cennych informatorów i skłaniania ich do szczerego dzielenia się lokalną wiedzą. Jak podkreślają autorzy, osoby te mogą być miejscowymi autorytetami, ale również tłumaczami, przewodnikami czy tubylczymi asystentami. $Z$ jednej strony są one bezpośrednio zaangażowane $\mathrm{w}$ proces etnograficznego postępowania, $\mathrm{z}$ drugiej współtworzą nierzadko towarzyskie wsparcie dla osamotnionego w obcym środowisku badacza. Bliskie relacje z tego typu partnerami pozwalają nie tylko przezwyciężyć pułapki językowego zrozumienia, ale umożliwiają także w miarę bezkonfliktowe poruszanie się w świecie nieznanego bliżej obyczaju i etykiety.

W tekstach tego działu znajdujemy również cenne uwagi na temat znaczenia specyficznej asymetrii, charakteryzującej $w$ terenie relacje między badaczem a badanymi przez niego ludźmi. Okazuje się, że te kwestie są także bardzo istotne, gdy zważyć na trudno przekraczalne bariery nie tylko kulturowe, ale także te, które wynikają z odmiennego statusu ekonomicznego, społecznego, ewidentnych różnic we wzajemnych interesach, poglądach na świat czy niełatwych do odwzajemnienia wyrazów sympatii i wdzięczności za udzieloną otwartość i gościnność. W refleksjach poruszających ten temat znajdujemy także cenne uwagi poświęcone strategiom zwiększającym szansę pozyskiwania przychylności i pomniejszania podejrzliwości czy nieufności wobec badacza. W tym kontekście przywoływane jest również ostrzeżenie co do potencjalnego niebezpieczeństwa, wynikającego z prób instrumentalnego „wykorzystania” obecności badacza do wewnętrznych rozgrywek pomiędzy poszczególnymi zwaśnionymi czy konkurującymi o wpływy grupami tej samej społeczności. Natomiast przebywanie w terenie 
z mężem/partnerem czy dzieckiem zdecydowanie ułatwia wejście w nowe środowisko, podobnie jak dostosowany do sytuacji i kontekstu kulturowego ubiór oraz wzbudzający zaufanie wygląd etnografa. Dość zgodnie autorzy tych esejów wskazują także na użyteczność uczestnictwa badacza w codziennych aktywnościach wspólnoty/rodziny/grupy, dzięki czemu pozyskiwane dane obserwacyjne pozwalają znacznie głębiej zrozumieć wypowiedzi mieszkańców i ich sposób życia. Interesującym wątkiem w tych dociekaniach jest również kwestia roli, znaczenia i możliwości wykorzystania $w$ trakcie badań przypadkowej sytuacji czy szczęśliwego trafu. Tego rodzaju niespodziewane wydarzenia zachęcają czasami do szybkiego skierowania badań na wcześniej nieplanowane tory, a praktyka taka uwidacznia, jak ważna jest $\mathrm{w}$ terenie elastyczność podejścia, umiejętność rezygnacji z utartych schematów i w miarę możliwości podążanie $\mathrm{w}$ ślad za toczącymi się $\mathrm{w}$ otoczeniu zdarzeniami.

Trzeci dział (Nowe pola, nowe doświadczenia) dotyka tych obszarów, które zdecydowanie wykraczają poza horyzont klasycznych penetracji antropologicznych. Dotyczą one całkiem nowych pól zainteresowań, a zatem i nowych doświadczeń terenowych. Refleksje na ten temat przedstawiają S. Pietrowiak, K. Świerk, Ł. Smyrski i T. Rakowski. Choć podejmowana przez tych autorów tematyka jest pozornie dość różnorodna (od antropologii krajobrazu, przez etnozoologię, studia nad światem niematerialnym, aż do poszukiwań „właściwej drogi" postępowania w badaniach terenowych), to jednak łączy ją jedna wspólna idea, mianowicie konsekwentne dążenie do twórczego poszerzania spektrum etnograficznej obserwacji o nowe, zwykle dotychczas mało eksplorowane obszary oraz próba zastosowania do ich interpretacji nowych antropologicznych narzędzi. W gruncie rzeczy przedmiotem autorefleksji jest tu również teren, a w zasadzie jego dwie odsłony; mamy więc do czynienia z klasycznym terenem etnografa penetrującego regiony zamieszkane przez ludy tubylcze oraz $\mathrm{z}$ "terenem metaforycznym", dostosowanym do badań współczesnych przejawów życia, jawiącym się jako obszar konstruowany przez badacza $\mathrm{z}$ sieci jego interakcji z wybranym typem/kategorią informatorów. W obu tych kontekstach intencją autorów było ukazanie walorów nowych ujęć i podejść, pozwalających $\mathrm{w}$ sposób oryginalny spojrzeć na analizowaną przez nich rzeczywistość społeczno-kulturową. Jeśli chodzi o pierwsze rozumienie terenu, to napotykamy w nim na nowe spojrzenie na krajobraz, jako na wypełnioną znaczeniami przestrzeń tworzącą ekumenę tubylczych społeczności, silnie powiązaną z lokalną ontologią, mitologią, historią etniczną i kategoriami kognitywnymi. Dzięki uwzględnieniu tych wszystkich czynników, antropolog może odsłonić specyficzne dla danej grupy więzy łączące ludzi z ich ojczystą ziemią, i potrafi ukazać, jak te pola egzystencjalnych relacji określają sensy i znaczenia wydarzeń z przeszłości, a także sytuacji współczesnych. Istotnym elementem takiego podejścia jest również rozpoznanie przyrodniczego środowiska zamieszkiwania tubylców. Chodzi o to, aby uchwycić sposób jego postrzegania i traktowania przez miejscowych, a zadanie to ułatwić może analiza lokalnej taksonomii i zasad jej konstruowania. Taki profil badań, zwykle umiejscawiany 
w obrębie studiów etnobiologicznych, wymaga od antropologa znacznej kompetencji zarówno w zakresie „zachodniej” wiedzy przyrodniczej, jak i dobrego rozpoznania tubylczej mitologii, folkloru, systemów kognitywnych, a także umiejętności etymologicznej interpretacji miejscowych nazw nadawanych zwierzętom i roślinom.

Dynamiczne poszerzanie spektrum antropologicznych obserwacji doprowadziło do zakwestionowania dotychczasowego, bardzo dosłownego, rozumienia "terenu" jako konkretnego pola działań etnografa w ściśle określonej przestrzeni geograficzno-społecznej. Szybko okazało się, że pojęcie to musi zostać gruntownie przewartościowane. O tym wyzwaniu w badaniach współczesności piszą także autorzy w tym dziale czasopisma. Podkreślają oni, opierając się na własnych doświadczeniach z penetracji etnograficznych prowadzonych i w Azji i w Polsce, że dzisiaj "terenem" najczęściej są pewne pola społecznych ról wraz z towarzyszącymi im układami kulturowymi. Tworzą one w istocie konkretne "skupiska interakcji”, w które wkracza badacz, kreując tym samym swój "teren”. Jedną z możliwych strategii postępowania może być w takiej sytuacji „antropologia kolaboratywna", a więc taka, która wiąże ściśle badacza z grupą osób przez niego badanych, sprawiając, iż obie strony współpracują efektywnie ze sobą, od wstępnego etapu pozyskiwania informacji, aż do zredagowania końcowego raportu. Tego rodzaju nowe podejście do „terenu” i jego „mieszkańców” sprawia, o czym piszą autorzy, że napotykamy $\mathrm{w}$ trakcie tego procesu na poważne problemy etyczne, związane z jednej strony z odpowiedzialnością wobec potencjalnych skutków ujawniania delikatnych informacji, z drugiej zaś z dylematem prewencyjnej autocenzury oraz pułapką autoryzacji, umożliwiającej ingerencję w treść uzyskanych rezultatów.

Ostatni dział (W poszukiwaniu minionego czasu) dotyka kwestii z pogranicza dociekań o charakterze etnohistorycznym i rozważań nad znaczeniem przeszłości oraz pamięci o dawnych wydarzeniach, oczywiście również w perspektywie praktyki terenowej. Okazuje się, że „poszukiwania minionego czasu” dostarczyć mogą badaczowi wiele satysfakcji, umożliwiając lepsze uchwycenie przebiegu zmian zachodzących w dłuższej perspektywie czasowej. Jednak w pewnych przypadkach - jak się okazuje - tak zorientowane studia nie spełniają planowanych oczekiwań lub wmontowują antropologa w kłopotliwą etycznie sytuację. Kwestie te w sposób bardzo interesujący i oparty na własnych doświadczeniach z prac prowadzonych w Brazylii, Indiach, Boliwii, i oczywiście w Polsce, przedstawiają P. Chyc, K. Kość-Ryżko, R. Beszterda i E. Kłosek.

Jednym z przewijających się wątków tych rozważań są poszukiwania śladów przeszłości. Jak się okazuje, poszukiwania te mogą wzbudzić w antropologu prawdziwy entuzjazm i satysfakcję z udanych badań, choć w innej sytuacji potrafią wywołać zwątpienie i rozczarowanie na skutek pojawienia się nieoczekiwanej rozbieżności między ambitnymi planami a skromnymi możliwościami ich realizacji. $W$ jednych przypadkach widoczne $\mathrm{w}$ krajobrazie i w lokalnych praktykach kulturowych ślady przeszłości, poszerzone dodatkowo penetracjami archiwalnymi, pozwalają badaczowi lepiej odtworzyć i zrozumieć 
przebieg kontaktów międzykulturowych (np. w wyniku działań misyjnych Braci Morawskich w Himalajach); w innych natomiast spore wysiłki, aby natrafić na opowieści zawierające przekazy o dziejach migracji i choćby okruchy pamięci o rodzinnych stronach wychodźców okazują się płonne (czytamy o tym w eseju o Brazylijczykach polskiego pochodzenia przybyłych do Parany z Bukowiny). Wspomniane tu przypadki ewidentnie pokazują, jak ważne jest zastosowanie w terenie elastycznego podejścia, które w zależności od sytuacji, z jaką spotyka się antropolog, musi ulec częściowemu przeorientowaniu, np. skupieniu się na kwestiach pierwotnie traktowanych dość drugorzędnie albo też odstąpieniu od niemożliwego do wykonania głównego celu i zajęciu się innymi ważnymi problemami badanej społeczności.

Drugi istotny wątek obecny w ostatnim dziale to znaczenie etnograficznych studiów narracyjnych w procesie prowadzącym nie tylko do rekonstrukcji przeszłości, ale pozwalającym zrozumieć traumatyczne doświadczenia wojenne i ich konsekwencje w codziennym życiu (casus polskich Sybiraków), jak i sensownie odczytać tubylcze kody kulturowe wynikające z odmiennych kategorii ontologicznych (casus Indian z boliwijskiej Amazonii). Jak pokazują to autorzy, badania tego rodzaju nie są łatwe zarówno ze względów metodycznych, jak i etycznych. I tak, intencjonalne wywoływanie tragicznych wspomnień z lat wojny i zsyłki w poważnym stopniu zakłócało dobrostan informatorów, wzbudzając w nich falę emocji, trudną również do opanowania przez samego badacza. Stąd też pojawiła się konieczność ograniczenia tego rodzaju rozmów i sięgnięcia do bardziej „wygodnej” strategii pozyskiwania danych, polegającej na interpretacji pisemnych relacji zesłańców, złożonych przez nich przed laty w archiwach. W ten sposób bezpiecznym "terenem" stały się po prostu zbiory wspomnień. Z kolei w kontaktach z amazońskimi tubylcami złudne okazały się próby uzyskania od nich opowieści o czasach minionych w formule "na żądanie”. Za to najbardziej efektywnym sposobem uchwycenia ich wspomnień o przeszłości było długotrwałe przebywanie $\mathrm{z}$ nimi, stałe dzielenie trudów ich codziennego życia oraz uważne wsłuchiwanie się w ich historie, opowiadane zazwyczaj „przy okazji”, a więc bez etnograficznej interwencji.

Wszystkie przytoczone w drugiej głównej części numeru doświadczenia, zarówno te, na które zwróciliśmy wyżej szczególną uwagę, jak oczywiście i pozostałe, nie mniej ważne oraz z pewnością również godne refleksji, ukazują niezwykłą różnorodność sytuacji, strategii, kontekstów, spotkań, przygód, incydentów, dylematów, z którymi w etnograficznym terenie, czy to z bliskim, czy dalekim, klasycznym, czy rozproszonym, antropolog ma zawsze do czynienia. Jednak na tym tle doświadczenia terenowe ks. Profesora Wojciecha Bębna, obejmujące bez mała trzy dekady wyjazdów do rdzennych społeczności wysp Pacyfiku i Australii, mają niewątpliwie wyjątkowy, oryginalny i zarazem niepowtarzalny wymiar. Sądzimy jednak, że impresje i refleksje z prac terenowych prowadzonych przez autorów tego jubileuszowego numeru czasopisma będą nie tylko symbolicznym gestem szacunku wobec dorobku i postawy Jubilata. Mamy nadzieję, że zainteresują one także wszystkich tych, dla których „teren” jest nie tylko laboratoryjnym 
obszarem pozyskiwania potrzebnych danych, ale stanowi szczególny obszar egzystencjalnych i zawodowych doświadczeń badacza, wynikających z jego bliskich relacji z mieszkańcami tego świata, którego zrozumienie jest jego celem.

\section{Literatura}

Barley, N. (1997). Niewinny antropolog. Notatki z glinianej chatki. Przeł. E.T. Szyler. Warszawa: Prószyński i S-ka.

Buliński, T., Kairski, M. (red.) (2011a). Teren w antropologii. Praktyka badawcza we wspótczesnej antropologii kulturowej. Poznań: Wydawnictwo UAM.

Buliński, T., Kairski, M. (2011b). Wiedza terenowa w antropologii: w poszukiwaniu nowego wymiaru badań terenowych. W: T. Buliński, M. Kairski (red.), Teren w antropologii. Praktyka badawcza we współczesnej antropologii kulturowej (s. 291-333). Poznań: Wydawnictwo UAM.

Holman, J.S. (2009). Autoetnografia. Polityka tego, co osobiste. W: N.K. Denzin, Y.S. Lincoln (red.), Metody badań jakościowych, t. 2 (s. 175-218). Przeł. M. Brzozowska-Brywczyńska. Warszawa: Wydawnictwo Naukowe PWN.

Kacperczyk, A. (2014). Autoetnografia - technika, metoda, nowy paradygmat? O metodologicznym statusie autoetnografii. Przegląd Socjologii Jakościowej, 10, 3, 32-74.

Kafar, M.A. (2009). O przełomie autoetnograficznym w humanistyce. W stronę nowego paradygmatu. W: B. Płonka-Syroka (red.), My i wy. Spór o profesjonalny charakter racjonalności nauki (s. 1-24). Warszawa: Wydawnictwo DiG.

Malinowski, B. (2008). Dziennik w ścistym znaczeniu tego wyrazu. Przeł. G. Kubica. Kraków: Wydawnictwo Literackie.

Rabinow, P. (2010). Refleksje na temat badań terenowych w Maroku. Przeł. K.J. Dudek, S. Sikora. Kęty: Antyk. Marek Derewiecki.

\section{SUMMARY}

Personal ethnography. Anthropologists in the field

The article presents the idea of personal ethnography, i.e. the anthropologists' individual experiences that include practical, existential, and emotional dimensions of ethnographic field research. Such experiences and their details are largely absent in scientific papers, due to their apparent irrelevance for research results. Nevertheless, they form an indispensable part of ethnographic research, influencing its scientific findings. This article not only emphasizes the need to include this aspect of ethnographic research in the methodological reflection, but also points out the differences and similarities between personal ethnography and autoethnography, following the main threads of personal experiences from fieldwork.

Keywords: anthropologists, fieldwork, personal ethnography, practical, existential and emotional dimension of ethnographic field research, autoethnography

Przeł. Agnieszka Bednarek-Bohdziewicz 